\title{
Comparison of the community structure of the marine molluses of the "Banco D. João de Castro" seamount (Azores, Portugal) with that of typical inshore habitats on the Azores archipelago
}

\author{
Sérgio P. Ávila • Frederico Cardigos • \\ Ricardo Serrão Santos
}

Received: 22 November 2005 / Revised: 26 May 2006 / Accepted: 27 October 2006 / Published online: 8 December 2006

(C) Springer-Verlag and AWI 2006

\begin{abstract}
D. João de Castro Bank (DJC) is a shallow seamount with hydrothermal activity located between the islands of Terceira and São Miguel, Azores (Portugal). A survey of the molluscan fauna was conducted in this peculiar habitat. We found a smaller number of molluscan taxa and a different community structure compared to shore environments on the Azores. This coincides with impoverished environmental settings at this location. Possible reasons such as the degree of isolation (inshore vs. offshore locations), geological age, and special ecological conditions related to seamounts and hydrothermal vents are discussed.
\end{abstract}

Keywords Seamounts $\cdot$ Molluscs $\cdot$ Azores · Hydrothermal vents $\cdot$ Modes of larval development

\section{Introduction}

D. João de Castro Bank $\left(38^{\circ} 13.3^{\prime} \mathrm{N} ; 26^{\circ} 36.2^{\prime} \mathrm{W}\right)$ is an isolated seamount located in the archipelago of the

Communicated by H.-D. Franke.

S. P. Ávila $(\square)$

Departamento de Biologia, Universidade dos Açores, 9501-801 Ponta Delgada, Açores, Portugal

e-mail: avila@notes.uac.pt

S. P. Ávila $\cdot$ F. Cardigos $\cdot$ R. S. Santos

IMAR (Centro do IMAR da Universidade dos Açores), Departamento de Oceanografias e Pescas,

Universidade dos Açores, 9901-862 Horta, Açores, Portugal

R. S. Santos

Departamento de Oceanografia e Pescas,

Universidade dos Açores, 9901862 Horta, Açores, Portugal
Azores (northern Atlantic), between the islands Terceira and São Miguel (Fig. 1a), at 36 and 40 nautical miles, respectively, from these islands. Today, the upper part of the seamount has its base at $50 \mathrm{~m}$ depth and reaches $13 \mathrm{~m}$ depth at its top. Inside the volcanic cone $(300 \times 600 \mathrm{~m})$, the depth is around $40 \mathrm{~m}$ (Fig. 1b). The shallower part of the seamount was formed by several submarine eruptions during 2 weeks in December 1720. These eruptions occurred at $100 \mathrm{~m}$ depth and were visible from São Miguel and Terceira. The ashes accumulated, forming a small island approximately $1 \mathrm{~km}$ across and $150 \mathrm{~m}$ high, which was completely destroyed by the winter storms 2 years later (Agostinho 1934, 1960; Weston 1964; Machado 1967).

Formations such as D. João de Castro Bank with exuberant hydrothermal activity at shallow depths are rare in the Atlantic Ocean (Santos et al. 1996). The gas is released within a small area $(100 \times 50 \mathrm{~m})$ at the bottom (16-45 m depth) in the western part of the volcanic cone. This gas, mainly $\mathrm{CO}_{2}(90 \%)$ with lesser $\mathrm{H}_{2} \mathrm{~S}$, $\mathrm{H}_{2}$, and $\mathrm{CH}_{4}$ (Cardigos et al. 2005), has its source in a magmatic chamber located between 1 and $5 \mathrm{~km}$ under the seafloor (Machado and Lemos 1998). Recently, a second area with hydrothermal activity was discovered, in the depth range of 150 to more than $400 \mathrm{~m}$, southeast of the shallowest part of the seamount (Pascoal et al. 2000). For a discussion on the chemical characterization of the fluids released by the vents at D. João de Castro Bank, see Cardigos et al (2005). The molluscan fauna at D. João de Castro Bank is still poorly known and has mainly been studied from a taxonomical point of view (Ávila 1997; Ávila et al. 2004). Nevertheless, seamounts provide opportunities to study the processes and patterns of dispersion and colonization in marine animals and contribute to the theories of 


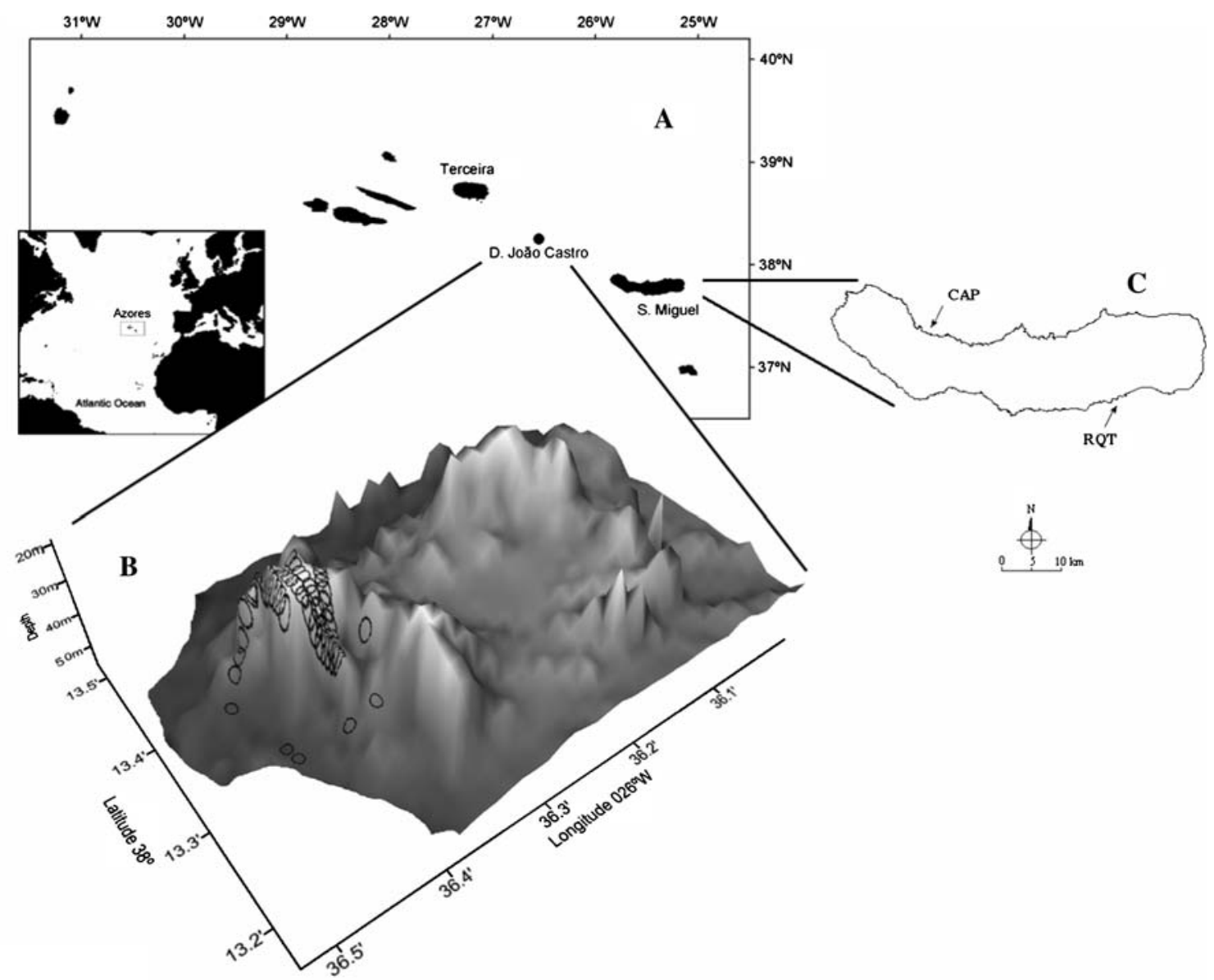

Fig. 1 a Geographic location of D. João de Castro Bank; b topography of D. João de Castro Bank ( ${ }^{\odot}$ ImagDOP and ISR/IST); c geographic location of Capelas (CAP) and Ribeira Quente (RQT) at São Miguel Island

biogeography and speciation (Shuto 1974; Scheltema 1995). The aim of this paper is to compare the molluscan community on this seamount with that of more typical inshore habitats on the Azores, and to relate possible differences to differences in the degree of isolation (inshore vs. offshore locations), geological age, type of substrate, depth, and the presence/absence of hydrothermal vents.

\section{Methods}

The molluscan fauna of D. João de Castro Bank (DJC), a shallow offshore bank with hydrothermal activity, was compared with two different inshore sites: Capelas (CAP), a rocky shore, densely covered by algae, without hydrothermal activity; and Ribeira Quente (RQT), a sandy area with hydrothermal activity (located on the north and south coast, respectively, of São Miguel; Table 1). In the Azores, there are no algae-covered inshore rocky sites with hydrothermal activity that could be compared with the DJC Bank.
Samples were obtained by SCUBA-diving. At each site, $25 \times 25 \mathrm{~cm}$ quadrates covered with algae were scraped off with a chisel. A total of 21 quadrates covered by algae were collected, 4 at DJC, 5 at RQT, and 12 at CAP (Table 3). The attached algae and associated organisms were collected into a labeled cotton drawstring bag with fine mesh net. In the laboratory, the samples were sieved by pouring water through a $1 \mathrm{~mm}$ mesh sieve. The molluscs were then removed from the algae, sorted to species level under a stereomicroscope, counted, labelled, and preserved in $70 \%$ ethanol. Only live molluscs were counted. All samples were given a number and were deposited in the collection of the Department of Biology of the University of the Azores (DBUA). The samples from CAP are a transformed subset of those published by Ávila (2003). The minimum area for subtidal quantitative ecological studies on algae, in the Azores is $50 \times 50 \mathrm{~cm}$ (Neto 1997), in contrast to $25 \times 25 \mathrm{~cm}$ for molluscan studies (Azevedo 1991; Ávila 1998). As scraping is a destructive technique, Ávila (2003) used the molluscan data from the algae area, so for the present study, the 
Table 1 Characterization of the samples

\begin{tabular}{|c|c|c|c|c|c|}
\hline Site & Date & $\begin{array}{l}\text { Depth } \\
\text { (m) }\end{array}$ & $\begin{array}{l}\text { Hydrothermal } \\
\text { activity }\end{array}$ & $\begin{array}{l}\text { Distance to } \\
\text { vents }(\mathrm{m})\end{array}$ & $\begin{array}{l}\text { Type of } \\
\text { substrate }\end{array}$ \\
\hline DJC1 & 22 July 2000 & 20.5 & 1 & 0.5 & Rocky \\
\hline DJC2 & 25 July 2000 & 16.9 & 4 & 0.3 & Rocky \\
\hline DJC3 & 25 July 2000 & 17.0 & 3 & 1.0 & Rocky \\
\hline DJC4 & 25 July 2000 & 16.0 & 3 & 1.3 & Rocky \\
\hline RQT1 & 28 September 2000 & 6.1 & 4 & 0.5 & Sandy \\
\hline RQT2 & 28 September 2000 & 6.6 & 2 & 0.3 & Sandy \\
\hline RQT3 & 28 September 2000 & 6.0 & 1 & 0.4 & Sandy \\
\hline RQT4 & 28 September 2000 & 5.9 & 2 & 0.5 & Sandy \\
\hline RQT5 & 28 September 2000 & 6.5 & 3 & 0.2 & Sandy \\
\hline CAP1 & 17 July 1996 & 16.0 & 0 & - & Rocky \\
\hline CAP2 & 17 July 1996 & 16.0 & 0 & - & Rocky \\
\hline CAP3 & 17 July 1996 & 16.0 & 0 & - & Rocky \\
\hline CAP4 & 11 July 1997 & 15.0 & 0 & - & Rocky \\
\hline CAP5 & 11 July 1997 & 15.0 & 0 & - & Rocky \\
\hline CAP6 & 11 July 1997 & 15.0 & 0 & - & Rocky \\
\hline CAP7 & 18 July 1996 & 8.0 & 0 & - & Rocky \\
\hline CAP8 & 18 July 1996 & 8.0 & 0 & - & Rocky \\
\hline CAP9 & 18 July 1996 & 8.0 & 0 & - & Rocky \\
\hline CAP10 & 10 July 1997 & 6.0 & 0 & - & Rocky \\
\hline CAP11 & 10 July 1997 & 6.0 & 0 & - & Rocky \\
\hline CAP12 & 10 July 1997 & 6.0 & 0 & - & Rocky \\
\hline
\end{tabular}

$D J C$ D. João de Castro Bank, RQT Ribeira Quente, CAP Capelas; the hydrothermal activity level was classified as: 0 no hydrothermal activity, 1 intermittent release of gas bubbles, 2 constant release of gas bubbles, 3 two or more vents per square meter with constant release of gas bubbles, 4 water heating and two or more vents per square meter with constant release of gas bubbles

original data of the $50 \times 50 \mathrm{~cm}$ CAP samples were transformed into a $25 \times 25 \mathrm{~cm}$ area by a simple division by the factor 4 .

\section{Data analysis}

Data analysis was carried out using the software package PRIMER v5.2 (Clarke and Gorley 2001). Species diversity was calculated using species richness $(S)$, and the species diversity indices of Shannon-Wiener $\left(H^{\prime}\right)$ (Pearson and Rosenberg 1978) and Pielou $\left(J^{\prime}\right)$ (Pearson and Rosenberg 1978; Warwick and Clarke 1993). Additionally, the total number of molluscs per sample $(N)$ was used for comparisons between sites. The associations between samples were visualized using the UPGMA clustering technique (Clarke and Warwick 1994). Prior to the analysis, data were transformed by double square root in order to standardize the data and to avoid clustering that would be determined by the most abundant species (Clarke 1993). Transformed species abundance $\left(n_{i}^{1 / 4}\right)$ was used to generate triangular matrices of similarities using the Bray-Curtis similarity index (Field et al. 1982; Clarke 1993).

The ANOSIM randomization/permutation test (Warwick and Clarke 1993) was used to test for differences between sites or selected sets of sites. These sets of sites were selected "a priori", based on their environmental conditions (e.g. sites with and without hydrothermal activity; inshore vs. offshore sites; sites with sand vs. rocky substrate). Species with a ratio higher than 1.4 (using SIMPER subroutine-similarity percentages analysis) were considered as mainly responsible for the dissimilarity between sites/sets of sites (Warwick et al 1990). Similarity percentages analysis examines the contribution of each species to the average Bray-Curtis dissimilarity, within and between groups of samples.

Diversity (species number) of DJC and CAP was compared using previous samples from both places: DJC-Ávila (1997), ASIMOV Expeditions in 1998, 1999 and 2000; Santos et al. (1996), Ávila et al. (2004); CAP_Ávila (2000c, 2003). The number of species was summed cumulatively (using species-area analysis implemented by PRIMER v 5.2; (Clarke and Gorley 2001) over all samples taken at those particular sites (irrespective of the technique employed) and plotted against the number of samples (Williamson 1990; Morri et al. 1999). A tendency line was added to the graph.

\section{Modes of development}

The mode of development of the caenogastropods was inferred by scanning electronic microscope pictures of the protoconch in the majority of the taxa, supplemented with data from literature when the species had 
a well-known life history. Two types of larval development were considered: non-planktotrophic (either lecithotrophic or direct development) and planktotrophic (i.e. with a free-swimming feeding larval stage) (Jablonski and Lutz 1983).

\section{Results}

A total of 2,360 molluscs with more than $1 \mathrm{~mm}$ were identified (337 at DJC, 219 at RQT, and 1,804 at CAP) (see Table 3). All taxa had already been described from the Azores (Ávila and Azevedo 1997; Ávila et al. 1998, 2000; Ávila 2000a, b). Forty-two taxa are known from the DJC Bank: 32 gastropods and 9 bivalves (some illustrated in Fig. 2), and 1 cephalopod (Ávila 1997; Ávila et al. 2004); no endemic vent species were found.

On average, species number and total number of specimens were lower at DJC and at sites with hydrothermal activity, when compared to CAP. The highest average diversity value $\left(H^{\prime}=1.67\right)$ was found at RQT, the other two sites had similar and lower diversity values (see Tables 2,3).

For each location, the maximum densities of the most common species are summarized in Table 4. A clear dominance of bivalves was found at DJC. Gregariella semigranata (Reeve 1858), a small bivalve with a Macaronesian and Mediterranean distribution, was the most abundant mollusc, with an average density ( \pm standard error) of $740 \pm 260 \mathrm{~m}^{-2}$ and a maximum value of $1,296 \mathrm{~m}^{-2}$. This species and Crassadoma pusio (Poli 1795) were the only species that occurred in all four samples collected at DJC. Anachis avaroides (Nordsieck 1975) and Columbella adansoni (Menke 1853) were common in only some of the DJC samples, but their densities at DJC were higher than at RQT and CAP. Bittium latreillii (Payraudeau 1826) occurred at DJC, but always in very low densities (maximum $192 \mathrm{~m}^{-2}$, average $6 \pm 2 \mathrm{~m}^{-2}$ ), while it was the most abundant species at CAP (maximum density $11,324 \mathrm{~m}^{-2}$, average $1,377 \pm 288 \mathrm{~m}^{-2}$ ) regardless of depth, followed by Tricolia pullus azorica (Dautzenberg 1889), an endemic subspecies that occurred in all CAP samples. Nassarius incrassatus (Ström 1768) was the most common species at RQT. B. latreillii, Parvicardium vroomi (van Aartsen, Moolenbeek and Gittenberger 1984), Rissoa guernei (Dautzenberg 1889) and also Tricolia pullus azorica were present with low densities in most RQT samples.

Clustering analysis shows a clear separation between sites with and without hydrothermal activity, all DJC samples grouping together, as well as RQT samples. There is also a split on the CAP samples, related with depth (shallow samples versus deeper samples) (Fig. 3).

The pre-defined groups of replicates (see Table 5) were compared against random simulations. A total of 20,000 permutations were used with the subroutine ANOSIM. The test statistic $R$ was low for the comparison between sites with rocky/sandy substrate. In the other comparisons (inshore/offshore sites; sites with/ without hydrothermal activity) the differences were higher (Table 6).

SIMPER analysis indicated that $G$. semigranata (Gre) and C. pusio (Cra) are responsible for more than $50 \%$ of the similarity of the samples collected at DJC. At RQT, the typical species is $N$. incrassatus (Nas), which is responsible for almost $40 \%$ of the similarity between the replicates of this location. B. latreillii (Bit) and Tricolia pullus azorica (Tpa) characterize the samples from CAP, defining $45 \%$ of the similarity. Inshore sites and sites without hydrothermal activity are typified by B. latreillii and Tricolia pullus azorica, whereas offshore sites are best defined by the presence of G. semigranata. B. latreillii is associated with a rocky substrate covered by algae, and $N$. incrassatus with a sandy bottom (Table 7). The absence of Tricolia pullus azorica at offshore sites and the higher densities of G. semigranata at these sites define the main differences between inshore and offshore mollusc communities found. The presence of Tricolia pullus azorica also distinguishes sites with and without hydrothermal activity, being very abundant especially in the shallow waters at CAP. This species had low densities at RQT and was absent from the quantitative samples at DJC.

Despite the low number of samples collected at DJC, it is possible to infer, by extrapolation, that for a similar collecting effort, the number of species is expected to be higher at CAP than at DJC (Fig. 4).

Modes of development

Of the 29 caenogastropods reported for the DJC Bank (Ávila 1997; Ávila et al. 2004), 8 have a non-planktotrophic type of larval development, 17 species are planktotrophic and for 4 species the mode of development remained unknown (Table 8).

\section{Discussion}

A pattern that appears from this and other studies (see Costa and Ávila 2001) is that the average numbers and densities of species are lower at hydrothermal vents than at similar sites without hydrothermal activity. At 

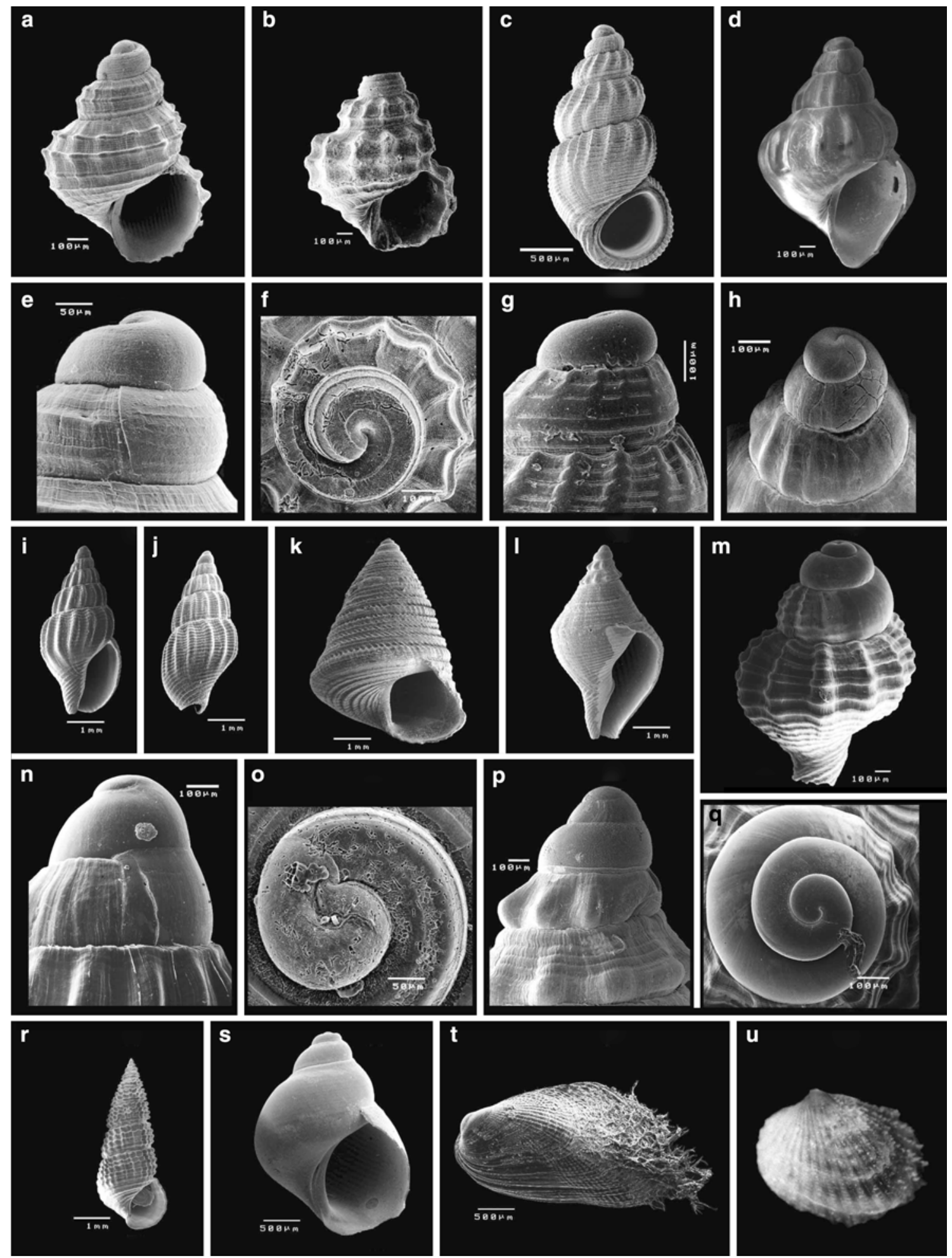

Fig. 2 a, e Alvania angioyi (van Aartsen 1982); a shell (DBUA 412/22-2), e protoconch (DBUA 335/23-3). b, f Alvania sleursi (Amati 1987); b shell (DBUA 446/34-1), f protoconch (DBUA 446/34-1). c, g Manzonia unifasciata (Dautzenberg 1889); c shell (DBUA 662/39-2), g protoconch (DBUA 181/49-2). d, h Rissoa guernei (Dautzenberg 1889); d shell (DBUA 662/10-2), h protoconch (DBUA 662/10-2). i, j, n Anachis avaroides (Nordsieck 1975); i shell (DBUA 785/56-1), j shell (DBUA 785/56-1), n protoconch (DBUA 785/63-2). k, oJujubinus pseudogravinae (Nord-

sieck 1973); k shell (DBUA 574/125-2), o protoconch (DBUA 350/14-9). I, p Columbella adansoni (Menke 1853); I shell (DBUA 570/59-1), p protoconch (DBUA 570/59-1). m, q Nassarius incrassatus (Ström 1768); m shell (DBUA 766-F/71-3), q protoconch (DBUA 766-F/71-3). r Bittium latreillii (Payraudeau 1826), shell (DBUA 701/13-1). s Tricolia pullus azorica (Dautzenberg 1889), shell (DBUA 767/68-1). t Gregariella semigranata (Reeve 1858), shell (DBUA 812/176-2). u Parvicardium vroomi (van Aartsen, Menkhorst and Gittenberger 1984), shell (DBUA 355) 


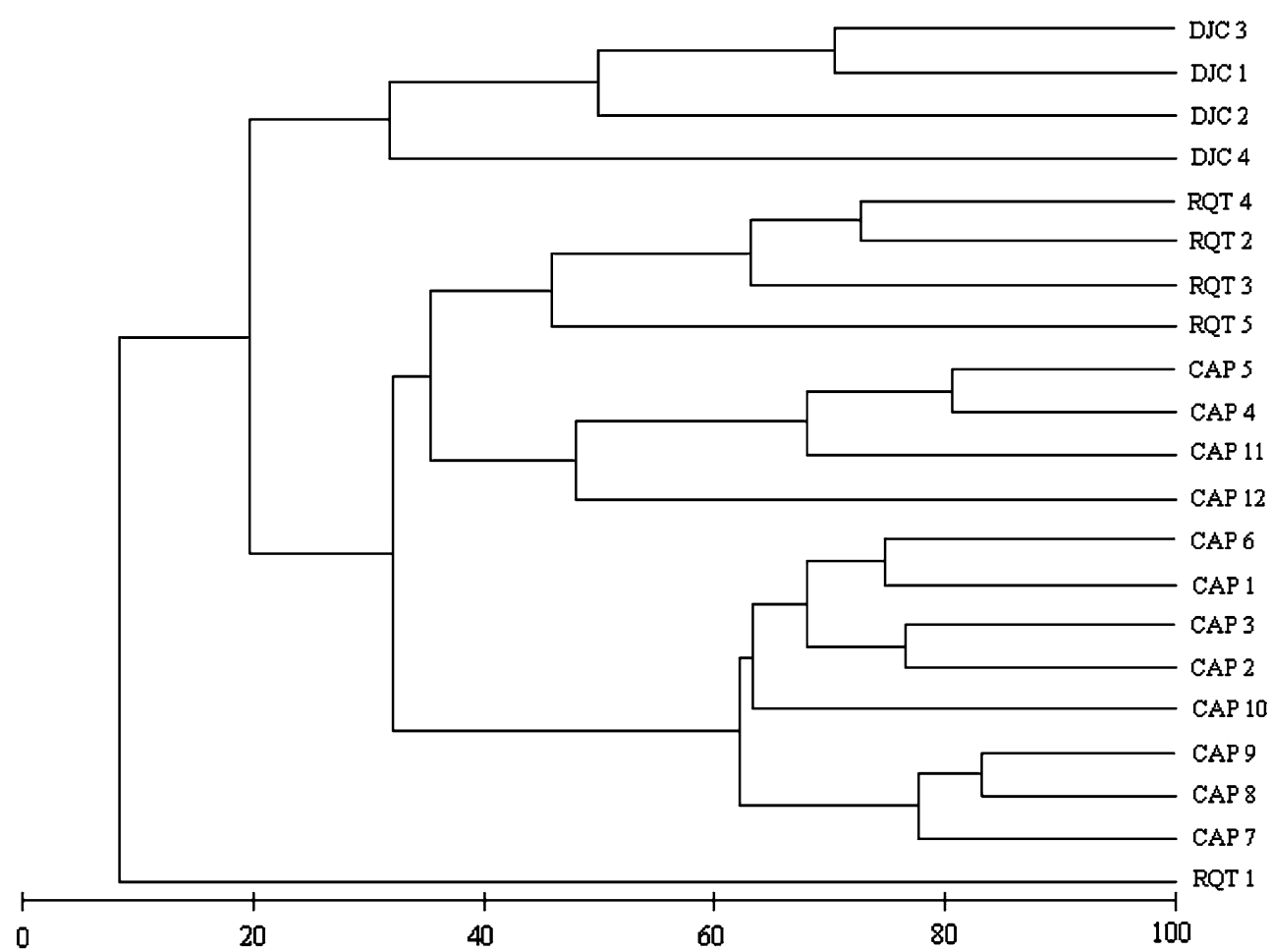

Fig. 3 Dendrogram of DJC, CAP, and RQT samples (abbreviations as in Table 3) (Bray-Curtis similarity index, UPGMA)

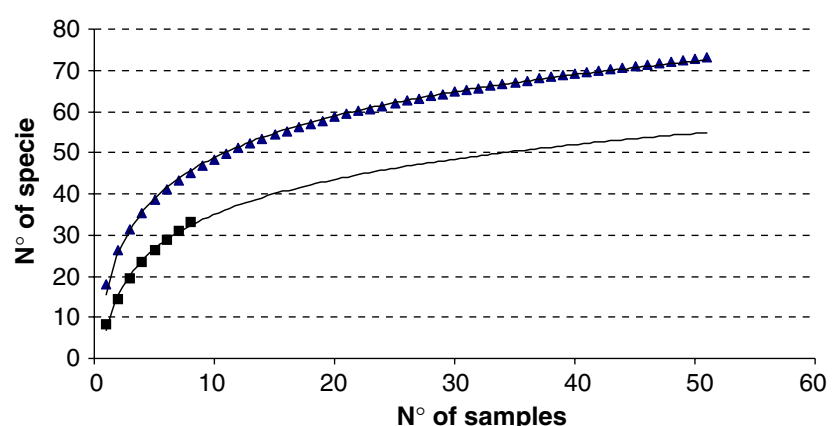

Fig. 4 Cumulative number of mollusc species plotted against the number of samples from the sites CAP (filled triangle) and DJC (filled square)

Kraternaya Bight (Kurile Islands), Tarasov et al. (1985, 1986, 1990) and Tarasov and Zhirmunskaya (1989) found that volcanic activity significantly changed the structure and specific composition of the communities. Comparable to these findings, we found striking changes in the relative densities of mollusc species in the presence of hydrothermal vents. In the Azores, in undisturbed environments (CAP), the most common littoral mollusc is B. latreillii (Ávila 2000c, 2003; Costa and Ávila 2001). This species, however, is not common at the shallow hydrothermal vents of RQT and DJC. The endemic Tricolia pullus azorica is common at RQT and in non-venting conditions (Ávila 2003), but only one operculum was found at DJC (Ávila et al.
Table 2 Diversity indices

\begin{tabular}{lllll}
\hline & $S$ & $N$ & $H^{\prime}$ & $J^{\prime}=H^{\prime} / \ln S$ \\
\hline DJC1 & 10 & 105 & 1.69 & 0.73 \\
DJC2 & 8 & 69 & 0.81 & 0.39 \\
DJC3 & 12 & 137 & 1.46 & 0.59 \\
DJC4 & 7 & 26 & 1.30 & 0.67 \\
DJC & 9 & 84 & 1.32 & 0.60 \\
RQT1 & 1 & 12 & 0.00 & - \\
RQT2 & 11 & 62 & 1.94 & 0.81 \\
RQT3 & 9 & 52 & 1.67 & 0.76 \\
RQT4 & 8 & 63 & 1.63 & 0.78 \\
RQT5 & 7 & 30 & 1.38 & 0.71 \\
RQT & 9 & 52 & 1.67 & 0.77 \\
CAP1 & 25 & 305 & 1.39 & 0.43 \\
CAP2 & 18 & 143 & 1.34 & 0.47 \\
CAP3 & 20 & 115 & 1.82 & 0.61 \\
CAP4 & 6 & 37 & 0.78 & 0.43 \\
CAP5 & 5 & 26 & 0.85 & 0.53 \\
CAP6 & 20 & 296 & 1.74 & 0.58 \\
CAP7 & 18 & 126 & 1.65 & 0.57 \\
CAP8 & 20 & 141 & 1.78 & 0.59 \\
CAP9 & 19 & 193 & 1.65 & 0.56 \\
CAP10 & 26 & 316 & 1.66 & 0.51 \\
CAP11 & 11 & 95 & 0.55 & 0.23 \\
CAP12 & 7 & 11 & 1.21 & 0.62 \\
CAP & 16 & 150 & 1.37 & 0.51 \\
\hline Valy & & & &
\end{tabular}

Values in italics represent the average values for DJC, RQT, and CAP samples (RQT1 was excluded from the calculation of the average values)

$S$ Number of species, $N$ total number of specimens, $H^{\prime}$ ShannonWiener diversity index, $J^{\prime}$ evenness; other abbreviations as in Table 1 


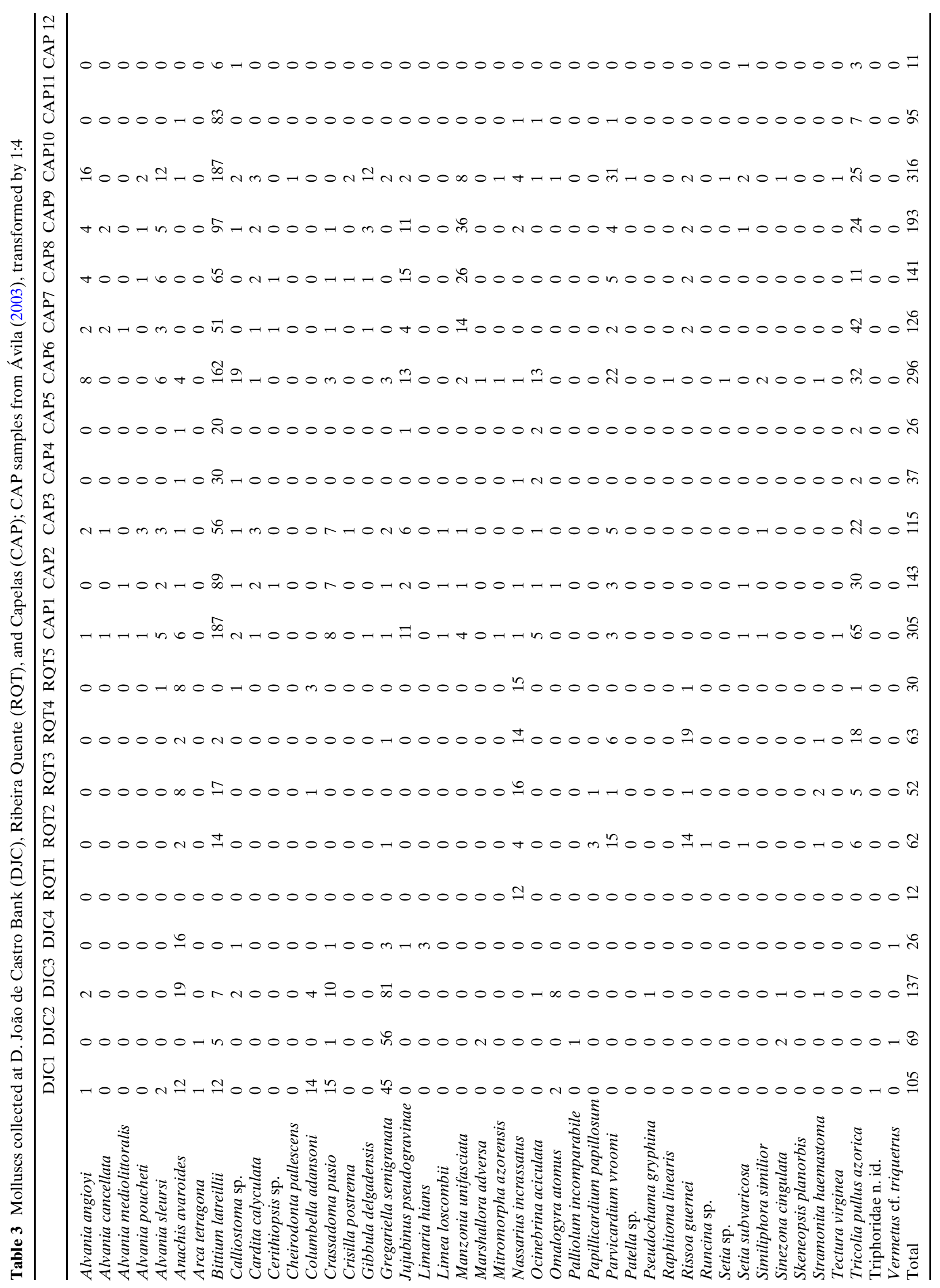


Table 4 Maximum densities of the most common molluscs collected at DJC, RQT and CAP (ind $\mathrm{m}^{-2}$ )

\begin{tabular}{llll}
\hline & DJC & RQT & CAP \\
\hline G. semigranata & 1,296 & 16 & 92 \\
C. pusio & 240 & 0 & 200 \\
A. avaroides & 304 & 128 & 144 \\
C. adansoni & 224 & 48 & 4 \\
N. incrassatus & 0 & 256 & 76 \\
B. latreillii & 192 & 272 & 11,324 \\
Tricolia pullus azorica & 0 & 288 & 1,032 \\
P. vroomi & 0 & 240 & 984 \\
R. guernei & 0 & 304 & 184 \\
A. angioyi & 32 & 0 & 256 \\
\hline For & & &
\end{tabular}

For abbreviations, see Table 1

Table 5 Pre-defined groups (with respective sampling sites) used for ANOSIM and SIMPER analysis

\begin{tabular}{ll}
\hline Pre-defined groups & Sampling sites \\
\hline Inshore & RQT, CAP \\
Offshore & DJC \\
Hydrothermal vents & DJC, RQT \\
Rocky substrate & DJC, CAP \\
Sandy substrate & RQT \\
\hline
\end{tabular}

For abbreviations, see Table 1

Table 6 ANOSIM results

\begin{tabular}{lll}
\hline Group comparisons & $R$ & $\begin{array}{l}\text { Significance } \\
\text { level (\%) }\end{array}$ \\
\hline Inshore/offshore & 0.672 & 0.1 \\
Hydrothermal activity/no activity & 0.526 & 0.1 \\
Rocky substrate/sandy substrate & 0.349 & 1.7 \\
\hline
\end{tabular}

Sampling sites are grouped according to Table 5

2004). At CAP, a non-venting site, B. latreillii, T. pullus azorica, Ocinebrina aciculata (Lamarck 1822) define almost $50 \%$ of the similarity of the samples. Nassariid gastropods were reported as dominant forms at Milos Island (Aegean Sea) reaching densities higher than $200 \mathrm{~m}^{-2}$ (Southward et al. 1997) and at Matupi Harbour (Rabaul Caldera, New Britain Island, Papua New Guinea) with densities of $13 \mathrm{~m}^{-2}$ (Tarasov et al. 1999); both sites exhibit submarine hydrothermal activity. In the Azores, $N$. incrassatus is a common species in sandy and muddy habitats, being especially abundant inside harbours (personal observation). This species was found at RQT in high numbers (maximum density $256 \mathrm{~m}^{-2}$ ), but although present at DJC (Ávila et al. 2004) and at CAP, its density in these locations was very low. Its abundance at RQT is thus probably related to the sandy type of bottom rather than to the hydrothermal conditions.

Many species associated with hydrothermal areas have adaptations (Ballard 1977; Grassle 1985) that allow them to survive in these extreme environments under the form of chemical contamination (Grassle et al. 1979) and/or extremely high temperatures (Jollivet et al. 1995). The trophic structure of shallowwater hydrothermal ecosystems differs from that of deep-sea hydrothermal ecosystems, which are dominated by chemosynthetic communities (Kharlamenko et al. 1995). At shallow-water hydrothermal vents, bacteria constitute a more important food source than at typical coastal ecosystems (Tarasov and Zhirmunskaya 1989; Kharlamenko et al. 1995). Rock samples collected from around the vent outlets at DJC were partially covered with bacterial mats, mainly an attached form of Beggiatoa (Cardigos et al. 2005).

The dominance of bivalves in DJC might thus be related to their filter-feeding habit which allows these animals to take advantage of the additional primary production by chemosynthetic bacteria living nearby the vents. This relationship was also used to explain the high diversity and density of Serpuloidea (Annelida: Polychaeta), also filter-feeders, in venting conditions on Milos Island (Bianchi and Morri 2000). No specialized hydrothermal molluscs were found at DJC or RQT, similarly to what was reported from other locations with shallow-water vents (Tarasov et al. 1986, 1990, 1999; Kamenev et al. 1993; Dando et al. 1995). Nevertheless, physiological and ecotoxicological tests are needed to study the tolerance to the toxic compounds that are released by these vents, such as $\mathrm{Cu}, \mathrm{Pb}$, $\mathrm{Ba}, \mathrm{Fe}, \mathrm{Mn}, \mathrm{Co}$, and Cd (Cardigos et al. 2005).

Similar to other seamounts around the Azores, DJC has a predominance of molluscs with a planktotrophic mode of development (17 taxa or $58.6 \%$ ). Although there is still a high number of Azorean caenogastropod species with unknown mode of development, preliminary results indicate that there is a slightly higher number of planktotrophic $(33.9 \%)$ relative to nonplanktotrophic caenogastropods $(29.8 \%)$ (Table 8$)$.

At Ormonde peak (the top of the eastern seamount of the Gorringe, located southwest of Portugal) Ávila and Malaquias (2003) investigated the mode of development of the caenogastropods located in the photic zone (down to $50 \mathrm{~m}$ depth) and found that from a total of 25 taxa, 11 species (44\%) were non-planktotrophic, whereas 14 taxa $(56 \%)$ were planktotrophic (Table 8). Leal (1991) did a similar study at Atol das Rocas (ROC) and Fernando de Noronha islands (NOR), located off the northeastern Brazilian coast, and at Trindade (TRI) and Martin Vaz Islands (MAR), located off the eastern Brazilian coast. We have modified his data by pooling his littoral and sublittoral species (down to $30-40 \mathrm{~m}$ depth) into a single category 
Table 7 SIMPER results

\begin{tabular}{|c|c|c|c|c|}
\hline Groups of sites & $\begin{array}{l}\text { Average } \\
\text { similarity }\end{array}$ & Species & $\begin{array}{l}\text { Species \% } \\
\text { (ratio of each species) }\end{array}$ & $\begin{array}{l}\text { Cumulative } \\
(\%)\end{array}$ \\
\hline DJC & 44.55 & Gre-Cra & $\begin{array}{l}33.22-19.23 \\
(3.59-5.53)\end{array}$ & 52.45 \\
\hline RQT & 47.67 & Nas & $\begin{array}{l}39.58 \\
(2.37)\end{array}$ & 39.58 \\
\hline CAP (all stations) & 51.19 & Bit-Tpa & $\begin{array}{l}27.14-17.84 \\
(2.81-2.93)\end{array}$ & 44.98 \\
\hline CAP (15-16) & 55.92 & Bit-Tpa-Oci-Ana & $\begin{array}{l}23.91-14.64-10.93-10.10 \\
(2.77-3.21-1.91-2.18)\end{array}$ & 59.58 \\
\hline CAP (6-8) & 48.54 & Bit-Tpa & $\begin{array}{l}28.20-19.93 \\
(3.17-3.06)\end{array}$ & 48.14 \\
\hline Inshore & 42.00 & Bit-Tpa & $\begin{array}{l}23.77-19.79 \\
(1.44-1.99)\end{array}$ & 43.56 \\
\hline Offshore & 44.55 & Gre-Cra & $\begin{array}{l}33.22-19.23 \\
(3.59-5.53)\end{array}$ & 52.45 \\
\hline With hydrothermal activity & 31.11 & - & No species with ratio $>1.4$ & - \\
\hline No hydrothermal activity & 51.19 & Bit-Tpa & $\begin{array}{l}27.14-17.84 \\
(2.81-2.93)\end{array}$ & 44.98 \\
\hline Rocky substrate & 40.36 & Bit & $\begin{array}{l}27.49 \\
(1.82)\end{array}$ & 27.49 \\
\hline Sandy substrate & 47.67 & Nas & $\begin{array}{l}39.58 \\
(2.37)\end{array}$ & 39.58 \\
\hline Groups & $\begin{array}{l}\text { Average } \\
\text { dissimilarity }\end{array}$ & Species & $\begin{array}{l}\text { Species \% } \\
\text { (ratio of each species) }\end{array}$ & $\begin{array}{l}\text { Cumulative } \\
(\%)\end{array}$ \\
\hline Inshore/offshore & 76.86 & Gre-Tpa & $\begin{array}{l}9.94-7.67 \\
(1.64-2.91)\end{array}$ & 17.60 \\
\hline $\begin{array}{l}\text { Hydrothermal activity/ } \\
\text { no activity }\end{array}$ & 71.72 & Tpa & $\begin{array}{l}6.90 \\
(1.47)\end{array}$ & 6.90 \\
\hline $\begin{array}{l}\text { Rocky substrate/ } \\
\text { sandy substrate }\end{array}$ & 72.09 & - & No species with ratio $>1.4$ & - \\
\hline
\end{tabular}

Ana A. avaroides, Bit B. latreillii, Cra C. pusio, Nas N. incrassatus, Oci O. aciculata, Tpa Tricolia pullus azorica, Gre G. semigranata; other abbreviations as in Table 1

Table 8 Number of caenogastropod species and mode of development

\begin{tabular}{|c|c|c|c|c|c|c|c|c|c|c|}
\hline Dev & $\mathrm{DJC}^{\mathrm{a}}$ & RQT & $\mathrm{CAP}^{\mathrm{b}}$ & $\mathrm{SMG}^{\mathrm{c}}$ & $\mathrm{AZO}^{\mathrm{d}}$ & $\mathrm{ORM}^{\mathrm{e}}$ & $\mathrm{ROC}^{\mathrm{f}}$ & $\mathrm{NOR}^{\mathrm{f}}$ & $\mathrm{TRI}^{\mathrm{f}}$ & MAR \\
\hline $\mathrm{np}$ & 8 & 5 & 21 & 35 & 37 & 11 & 50 & 57 & 39 & 15 \\
\hline $\mathrm{p}$ & 17 & 5 & 21 & 41 & 42 & 14 & 25 & 48 & 38 & 11 \\
\hline Unknown & 4 & 0 & 7 & 39 & 45 & 0 & 3 & 5 & 0 & 0 \\
\hline \# Caen & 29 & 10 & 49 & 115 & 124 & 25 & 78 & 110 & 77 & 26 \\
\hline \# Total & 42 & 10 & 71 & 223 & 347 & 36 & - & - & - & - \\
\hline
\end{tabular}

$n p$ non-planktotrophic, $p$ planktotrophic, \# Caen number of caenogastropods, \# Total total number of molluscan taxa, ORM Ormonde seamount (Gorringe bank), ROC Atol das Rocas, NOR Fernando de Noronha, TRI Trindade Island, MAR Martin Vaz; other abbreviations as in Table 1

a Ávila (1997); Ávila et al. (2004)

b Ávila (2003)

c Ávila et al. (2000)

d Ávila (2000a, b, c, 2005)

e Ávila and Malaquias (2003)

f Leal (1991)

and by using only two modes of development: nonplanktotrophic (with pooled lecithotrophic and direct development) and planktotrophic. At TRI there is an equilibrium between both modes of development, whereas at ROC, NOR and MAR there is a higher number of species with non-planktotrophic development (Table 8). This is especially evident at ROC, the island nearest to Brazil, located just $200 \mathrm{~km}$ off the coast, with $64 \%$ of non-planktotrophic and $32 \%$ of planktotrophic species. 
The bias in favour of planktotrophic developers is probably related to the relatively early age of the DJC Bank (less than 300 years), its higher degree of isolation from source populations, and the small area (only $300 \times 600 \mathrm{~m}$ above $50 \mathrm{~m}$ depth). For non-planktotrophic species such as Calliostoma sp., Jujubinus pseudogravinae, Alvania angioyi, Alvania sleursi, A. avaroides and Omalogyra atomus, and especially for those with direct development, the major problem is to reach this seamount. Once there, and provided the species' ecological demands are met, gravid females may give rise to new successful populations (Leal 2000). Planktotrophic species may reach DJC Bank with higher frequencies than non-planktotrophic ones, but they will meet with greater difficulties in establishing self-sustained populations, because most larvae will get lost by drifting away from the small area of the seamount. As a consequence, these "pseudopopulations" (Bouchet and Taviani 1992) can persist only by a regular input of larvae from other source-locations, in the case of DJC from nearby islands of the Azores archipelago (e.g. Terceira and São Miguel).

The absence at DJC of species common on the intertidal zone of the Azorean shores (e.g. the littorinids: Littorina striata and Melarhaphe neritoides, the little skeneopsid: Skeneopsis planorbis, the anabathrid: Pisinna glabatra, and the rissoids: Cingula trifasciata and Alvania mediolittoralis) must be related to a lack of the physical and/or biotic conditions typical of littoral zones. The highest elevation of DJC is at around $13 \mathrm{~m}$ depth. Consequently, species that usually live in the upper $10 \mathrm{~m}$ can be expected to be absent from the DJC Bank. Ávila (2003) established the zonation pattern for the most common shallow marine molluscs of the Azores. From these data and the mollusc checklists of DJC (Ávila 1997; Ávila et al. 2004) it is evident that why many common littoral Azorean shore species are missing at DJC (e.g. the rissoids: $R$. guernei and Manzonia unifasciata, the trochid: Gibbula delgadensis).

Features inherent to offshore shallow seamounts, such as turbulent hydrodynamic conditions, both currents and waves, are likely to result in reduced diversity and abundance of species, as seen at DJC. On the other hand, this may explain the higher numbers of the two mentioned bivalves, one (Crassadoma) cemented to the substrate, and the other (Gregariella) attached byssally.

Acknowledgments The first author wishes to express his gratitude for the invitation to participate in ASIMOV 2000 scientific expedition to D. João de Castro bank. We also wish to thank Vítor Rosa, Renato Bettencourt, Luís Quinta (also for the photos), and Joe Pimentel for their field support, and Paul Dando, Helen Rost Martins, José M. N. Azevedo, Thierry Backeljau, and
Patrick Van Riel for the scientific suggestions that greatly improved this manuscript. We thank Rogério Ferraz (DOP/UA) for Fig. 1, and Jorge Medeiros (CIRN/UA) is acknowledged for the SEM photos. S.P.A. was supported by grants SFRH/BD/5115/ 2001 and SFRH/BPD/22913/2005 (FCT_Fundação para a Ciência e Tecnologia) of the Portuguese government. The European Community through contract MAS3-CT97-0092 financed the ASIMOV Project. We also thank ImagDOP, the image, and multimedia nucleus of the Department of Oceanography and Fisheries of the University of the Azores.

\section{References}

Agostinho J (1934) The volcanoes of the Azores. Bull Volcanol 8:123-138

Agostinho J (1960) Actividade vulcânica nos Açores. Açoreana 5:362-478

Ávila SP (1997) Moluscos marinhos recolhidos no Banco "D. João de Castro". Açoreana 8:331-332

Ávila SP (1998) Zonação intertidal de uma comunidade malacológica numa lagoa costeira localizada na costa Sul da ilha do Pico, Açores. Açoreana 8:436-486

Ávila SP (2000a) Shallow-water marine molluscs of the Azores: biogeographical relationships. Arquipélago, Suppl 2 (Part A):99-131

Ávila SP (2000b) The shallow-water Rissoidae (Mollusca, Gastropoda) of the Azores and some aspects of their ecology. Iberus 18:51-76

Ávila SP (2000c) Sistemática e ecologia dos Moluscos (Gastropoda, Bivalvia e Polyplacophora) litorais em São Vicente, Capelas (São Miguel, Açores). MSc. Thesis, University of the Azores, Ponta Delgada, Portugal (in press)

Ávila SP (2003) The littoral molluscs (Gastropoda, Bivalvia and Polyplacophora) of São Vicente, Capelas (São Miguel Island, Azores): ecology and biological associations to algae. Iberus 21:1-23

Ávila SP (2005) Processos e Padrões de Dispersão e Colonização nos Rissoidae (Mollusca: Gastropoda) dos Açores. Ph.D. Thesis, University of the Azores, Ponta Delgada, Portugal (in press)

Ávila SP, Azevedo JMN (1997) Shallow-water molluscs from the Formigas islets, Azores, collected during the "Santa Maria e Formigas 1990" scientific expedition. Açoreana 8:323-330

Ávila SP, Malaquias MA (2003) Biogeographical relationships of the molluscan fauna of the Ormonde seamount (Gorringe bank, Northeast-Atlantic Ocean). J Molluscan Stud 69:145-150

Ávila SP, Azevedo JMN, Gonçalves JM, Fontes J, Cardigos F (1998) Checklist of the shallow-water marine molluscs of the Azores: 1-Pico, Faial, Flores and Corvo islands. Açoreana 8:487-523

Ávila SP, Azevedo JMN, Gonçalves JM, Fontes J, Cardigos F (2000) Checklist of the shallow-water marine molluscs of the Azores: 2-São Miguel island. Açoreana 9:139-173

Ávila SP, Cardigos F, Santos RS (2004) D. João de Castro bank, a shallow-water hydrothermal-vent in the Azores: checklist of the marine mollusks. Arquipélago 21A:75-80

Azevedo JMN (1991) Estudo das comunidades malacológicas fitais do litoral em São Miguel, Açores. MSc. Thesis, Universidade dos Açores, Ponta Delgada (in press)

Ballard RD (1977) Notes on a major oceanographic find. Oceanus 20:35-44

Bianchi CN, Morri C (2000) Serpuloidea (Annelida: Polychaeta) from Milos, an island in the Aegean Sea with submarine hydrothermalism. J Mar Biol Assoc UK 80:259-269 
Bouchet P, Taviani M (1992) The Mediterranean deep-sea fauna: pseudopopulations of Atlantic species? Deep Sea Res 39:169-184

Cardigos F, Colaço A, Dando PR, Ávila SP, Sarradin P-M, Tempera F, Conceição P, Pascoal A, Santos RS (2005) Shallow water hydrothermal vent field fluids and communities of the $\mathrm{D}$. João de Castro Seamount (Azores). Chem Geol 224:153-168

Clarke KR (1993) Non-parametric multivariate analysis of changes in community structure. Aust J Ecol 18:117-143

Clarke KR, Gorley RN (2001) PRIMER v5: user manual/tutorial. PRIMER-E, Plymouth, UK

Clarke KR, Warwick RM (1994) Change in marine communities: an approach to statistical analysis and interpretation. Natural Environment Research Council, UK

Costa AC, Ávila SP (2001) Macrobenthic mollusc fauna inhabiting Halopteris spp. subtidal fronds in São Miguel island, Azores. Sci Mar 65:117-126

Dando PR, Hughes JA, Thiermann F (1995) Preliminary observations on biological communities at shallow hydrothermal vents in the Aegean Sea. In: Parson LM, Walker CL, Dixon DR (eds) Hydrothermal vents and processes. Geological Society Special Publication 87, London, pp 303-317

Field G, Clarke KR, Warwick RM (1982) A practical strategy for analysing multispecies distribution patterns. Mar Ecol Prog Ser 8:37-52

Grassle JF (1985) Hydrothermal vent animals: distribution and biology. Science 229:713-717

Grassle JF, Berg CJ, Childress JJ, Grassle JP, Hessler RR, Jannasch HJ, Karl DM, Lutz RA, Mickel TJ, Rhoads DC, Sanders HL, Smith KL, Somero GN, Turner RD, Tuttle JH, Walsh PJ, Williams AJ (1979) Galapagos '79: initial findings of a deep-sea biological quest. Oceanus 22:2-10

Jablonski D, Lutz RA (1983) Larval ecology of marine invertebrates: paleobiological implications. Biol Rev 58:21-89

Jollivet D, Desbruyeres D, Ladrat C, Laubier L (1995) Evidence for differences in the allozyme thermostability of deep-sea hydrothermal vent polychaetes (Alvinellidae): a possible selection by habitat. Mar Ecol Prog Ser 123:125-136

Kamenev GM, Fadeev VI, Selin NI, Tarasov VG, Malakhov VV (1993) Composition and distribution of macro- and meiobenthos around sublittoral hydrothermal vents in the Bay of Plenty, New Zealand. N Z J Mar Freshw Res 27:407-418

Kharlamenko VI, Zhukova NV, Khotimchenko SV, Svetashev VI, Kamenev GM (1995) Fatty acids as markers of food sources in a shallow-water hydrothermal ecosystem (Kraternaya Bight, Yankich Island, Kurile Islands). Mar Ecol Prog Ser 120:231-241

Leal JH (1991) Marine prosobranch gastropods from oceanic islands off Brazil, species composition and biogeography. Universal Book Services/Dr. W. Backhuys, Oegstgeest

Leal JH (2000) Endemism and modes of development of marine prosobranch gastropods (Mollusca) from oceanic islands off Brazil. Arquipélago Suppl 2(Part A):89-97

Machado F (1967) Active volcanoes in the Azores. In: van Padang N, Richards AF, Machado F, Bravo T, Baker E, le Maitre W (eds) Catalogue of the active volcanoes of the world, part 21. International Association of Volcanology, Roma, pp 7-52

Machado F, Lemos R (1998) Sobre uma possível erupção submarina no Banco D. João de Castro em 1997. Açoreana 8:559-564

Morri C, Bianchi CN, Cocito S, Peirano A, de Biase AM, Aliani S, Pansini M, Boyer M, Ferdeghini F, Pestarini M, Dando P (1999) Biodiversity of marine sessile epifauna at an Aegean island subject to hydrothermal activity: Milos eastern Mediterranean Sea. Mar Biol 135:729-739
Neto AI (1997) Studies on algal communities of São Miguel, Azores. Ph.D. thesis, Universidade dos Açores, Ponta Delgada (in press)

Pascoal A, Oliveira P, Silvestre C, Sebastião L, Rufino M, Barroso V, Gomes J, Ayela G, Coince P, Cardew M, Ryan A, Braithwaite H, Cardew N, Trepte J, Seube N, Champeau J, Dhaussy P, Sauce V, Moitié R, Santos RS, Cardigos F, Brussieux M, Dando P (2000) Advance system integration for managing the coordinated operation of robotic ocean vehicles (ASIMOV). EuroOCEANS 2000

Pearson T, Rosenberg R (1978) Macrobenthic succession in relation to organic enrichment and pollution of the marine environments. Oceanogr Mar Biol Annu Rev 16:229-311

Santos RS, Gonçalves J, Cardigos F (1996) D. João de Castro Bank. Report to the European Community under contract INTAS project $94-0592: 1-5$

Scheltema RS (1995) The relevance of passive dispersal for the biogeography of Caribbean mollusks. Am Malacol Bull 11:99-115

Shuto T (1974) Larval ecology of prosobranch gastropods and its bearing on biogeography and paleontology. Letahia 7:239256

Southward AJ, Southward EC, Dando PR, Hughes JA, Kennicutt MC II, Alcalá-Herrera J, Leahy Y (1997) Behaviour and feeding of the nassariid gastropod Cyclope neritea, abundant at hydrothermal brine seeps off Milos (Aegean Sea). J Mar Biol Assoc UK 77:753-771

Tarasov VG, Zhirmunskaya AV (1989) Investigation of the ecosystem of Kraternaya Bight (Kurile Islands). Sov J Mar Biol 15:139-148

Tarasov VG, Propp MV, Propp LN, Kamenev GM, Blinov SV (1985) Shallow hydrothermal vents and a unique ecosystem of Kraternaya Caldera (Kurile Islands). DVNC AN SSSR, Vladivostok

Tarasov VG, Propp MV, Propp LN, Blinov SV, Kamenev GM (1986) Shallow hydrothermal vents and a unique ecosystem of Kraternaya Caldera, Kurile Islands (in Russian with English summary). Biol Morya (Mar Biol Vladivostok) 2:72-74

Tarasov VG, Propp MV, Propp LN, Zhirmunskaya AV, Namsaraev BB, Gorlenko VM, Starynin DA (1990) Shallow-water gaseo-hydrothermal vents of Ushishir Volcano and the ecosystem of Kraternaya Bight (The Kurile Islands). PSZN I Mar Ecol 11:1-23

Tarasov VG, Gebruk AV, Shulkin VM, Kamenev GM, Fadeev VI, Kosmynin VN, Malakhov VV, Starynin DA, Obzhirov AI (1999) Effect of shallow-water hydrothermal venting on the biota of Matupi Harbour (Rabaul Caldera, New Britain Island, Papua New Guinea). Cont Shelf Res 19:79-116

Warwick R, Clarke K (1993) Comparing the severity of disturbance: a meta-analysis of marine macrobenthic community data. Mar Ecol Prog Ser 92:224-231

Warwick R, Platt H, Clarke K, Agard J, Gobin J (1990) Analysis of macrobenthic and meiobenthic community structure in relation to pollution and disturbance in Hamilton harbour, Bermuda. J Exp Mar Biol Ecol 138:119-142

Weston FS (1964) List of recorded volcanic eruptions in the Azores with brief reports. Boletim do Museu e Laboratório Mineralógico e Geológico da Universidade de Lisboa, vol 10, pp 3-18

Williamson M (1990) Relationship of species number to area, distance and other variables. In: Myers AA, Giller PS (eds) Analytical biogeography. An integrated approach to the study of animal and plant distributions. Chapman and Hall, New York, pp 91-115 